\title{
Rеввавси автісів: Credit need of the farmers in Bikaner region of Rajasthan
}

\section{口AJU KUMAWAT, B.L. DHAYAL AND N.K. SINGH}

Article Chronicle: Received :

19.04.2017;

Revised :

03.06.2017;

Accepted :

17.06.2017

KEY Words:

Credit need, Farmers, Large farms, Live stock

Author for correspondence :

\section{B.L. DHAYAL}

Krishi Vigyan Kendra, VADODARA (GUJARAT) INDIA

Email:dhayalextn@yahoo. co.in

See end of the article for authors' affiliations
SUMMARY : The credit need to the farmers of Sriganganagar and Hanumangarh was about 40-42 per cent and 68 to 74 per cent to the farmers of Bikaner and Churu district of the total amount registered for recommended dose of inputs. In case of term loan about 42 to 54 per cent was needed to the farmers of study area for purchasing of farm equipments and machinery, minor irrigation system and for land development purposes. Of the credit need about 28 to 49 per cent short term credit was supplied to the farmers of study area. In case of term credit about 50 to 69 per cent term loan was supplied to the borrower farmers by financial institutions in study area. Purpose wise highest term credit (58 to $54 \%$ ) was provided for farm machinery and equipment to the farmers of Hanumangarh and Sriganganagar district. However, the higher 54-60 per cent term credit was supplied for minor irrigation to the farmers of Bikaner and Churu district. The total credit supplied varied from 82 to 87 per cent of the total credit need. The utilization pattern of the short term credit among small, medium and large farms of the study area was about 68 per cent (small) to 92 per cent (large farms). On an average utilized amount of the short term loan by the farmers of Bikaner region as whole was about 77 to 85 per cent of the total credit supplied for production purposes. About 79 to 85 per cent term loan and 82 to 87 per cent total loan was utilized by the farmers of Bikaner region. The short term credit gap of the borrower farmers of Bikaner region was estimated about 13 to 19 per cent, however, the supply gap in respect of term credit was 19 to 48 per cent of the total term credit need. The financial institutions preferred to provide the credit to the farmers having larger land holding. The repayment performance was found higher on small farmers followed by medium and large farmers in the study area. The repayment performance of short term loan on overall level was about 69 to 86 per cent. About 65 to 85 per cent difference farm large to small farms was found in repayment performance in the study area. The overdues amount was increased with increase in size of land holding. The extent of overdues increase of term loan ranged 15 to 33 per cent. The gross farm income, non farm income, cropping intensity, amount put for productive purposes and total land holding was significantly negative effect in overdues and variables such as amount put for unproductive farm expenses, old debts, live stock expenditure were having positive relationship with overdues.

How to cite this article : Kumawat, Raju, Dhayal, B.L. and Singh, N.K. (2017). Credit need of the farmers in Bikaner region of Rajasthan. Agric. Update, 12(3): 328-337; DOI : 10.15740/HAS/AU/12.3/328-337. 